\title{
In Vitro and in Vivo Management of Fusarium Wilt of Cucumber (FWC) Through Various Chemicals
}

\author{
Ghulam Fareed $^{1}$, Muhammad Atiq ${ }^{1}$, Manzar Abbas ${ }^{2}$, Muhammad Usman ${ }^{2}$, Ghulam Abbas ${ }^{3, *}$, \\ Khawar Hayat ${ }^{3}$ \\ ${ }^{1}$ Department of Plant Pathology, Faculty of Agriculture, University of Agriculture Faisalabad, Pakistan \\ ${ }^{2}$ Centre of Agriculture Biochemistry and Biotechnology, Faculty of Agriculture, University of Agriculture Faisalabad, Pakistan \\ ${ }^{3}$ Department of Poultry Science, Faculty of Animal Husbandry, University of Agriculture Faisalabad, Pakistan
}

Copyright (C) 2015 by authors, all rights reserved. Authors agree that this article remains permanently open access under the terms of the Creative Commons Attribution License 4.0 International License.

\begin{abstract}
Various fungicidal chemicals were evaluated against the fusarium wilt of cucumber disease. Firstly chemicals were evaluated under lab conditions and the best resulted fungicides were applied in field conditions and significant disease incidence reduction had been recorded as compared to control. Five chemicals namely redomil, score, copper oxychloride, cabriotop, antracol and a control were applied in lab conditions in three concentrations $1 \%, 0.5 \%$ and $0.25 \%$ following randomized complete block design (RCBD). Maximum growth inhibition of fungus mycelia was expressed by redomil $(1.53 \mathrm{~cm})$ followed by score $(1.66 \mathrm{~cm})$, copper oxychloride $(1.75 \mathrm{~cm})$, cabriotop $(1.79 \mathrm{~cm})$, and antracol $(1.90 \mathrm{~cm})$ as compared to control $(3.49 \mathrm{~cm})$. Hence redomil $(1.53 \mathrm{~cm})$ and score $(1.66 \mathrm{~cm})$ gave maximum inhibition under lab conditions these were applied to highly susceptible Local variety in same concentrations and same design cultivated in Research Area of the Department of Plant Pathology University of Agriculture Faisalabad. Redomil (47.50\%) expressed minimum disease incidence and score (49.72\%) as compared to control in field $(55.0 \%)$.
\end{abstract}

Keywords Fusarium Wilt, Cucumber, Redomil, Score, Copper Oxychloride, Cabriotop, Antracol

\section{Introduction}

The cucumber (Cucumis sativus L.) is the most prominent member of large group of vegetables of the family cucurbitaceae. It has remarkable economic and dietary value. The mature fruits are used as salad and the immature fruits are used in pickles. Its plant is a coarse prostrate, annual vine with stiff hairs or spines on leaves and stems $[1,2]$.

Cucumis sativus exhibits monoecious annual creeping behavior $[3,4]$ and has been cultivated from more than 3000 years ago till toay. It is soft, succulent with high water content. It has a sufficient amount of vitamins A, C, K, B6, potassium and gives also dietary fibers, pantothenic acid, magnesium, phosphorus, copper and manganese [5].

However pickling process reduces the amount of nutrients especially vitamin C [6]. It contains ascorbic acid and caffeic acid, both of which help to smoothen the skin irritation and reduces swelling. Its skin contains chlorophyll and silica, two beneficial elements that are lost when the vegetables are peeled. Its juice is often suggested as a source of silicon to develop the complexion and health of the skin [7].

Its fruit has some essential vitamins and antioxidants which affect the human health significantly. Further it has cucurbitacin $\mathrm{C}$. This is a terpene that is designed in foliage and fruits. It shelters the fruit from insect attack [8].

China gives leading production of $40,709,556$ tons every year [9]. In Pakistan despite its low production it is a main vine crop. Its cultivation is increasing gradually due to its medicinal and other valuable aspects. Twelve hudreds hectares with a production of 7300 tons was cultivated in 2010 [10]. However 10-50\% losses are estimated by this disease in major areas of Pakistan with a serious disease attack in Punjab [11]. Pathogen attacks cucumber plants throughout the world severely. Pathogen Fusarium oxysporum f.sp. cucumerinum is the causal agent of fusarium wilt disease of cucumber and proved as most damaging pathogen [12].

No doubt the genomes available to us have a little level of resistance against wilt pathogen. To manage the fusarium wilt disease attack we have no reliable, cost effective, efficient and applicable way up to now. But some practices are there which are suggested to overcome the pathogen attack one of them is fungicide application. It is a rapid and fast method $[13,14]$.

Pathogen is soil borne and remains alive in soil over years, so simple agronomic practices to eliminate the pathogen are not feasible such as crop rotation. So the control of pathogen is very hard owing to its own genetically resistance reaction and also its characteristic to stay alive in soil saprophytically for many years [15].

Use of fungicides for fusarium wilt of cucumber is the most common way which is adopted commercially. 
Fungicide is a quick management strategy to control fungal pathogens whereas highly resistant genome to avoid disease is not available [16]. Therefore supremacy of chemicals above other tools is efficient and rapid disease management technique [17]. So, the intent of this investigation was to investigate the effect of different chemicals to manage fusarium wilt disease of cucumber.

\section{Materials and Method}

Different fungicides viz. Redomil, Score, Copper oxychloride, Cabriotop, Antracol were evaluated against fusarium wilt of cucumber on three replication and one control under lab conditions at three concentrations $(1 \%$, $0.5 \%$, and $0.25 \%$ ). Concentrations which are used are made by considering their active ingredient percentage. These treatments were applied randomly to each plate filled with potato dextroxe agar (PDA) media with fungus culture of Fusarium oxysporum f.sp.cucumerinum. Mycelial growth with each treatment was measured with the help of scale with one week interval. The best resulted fungicides were evaluated against the highly susceptible Local cucumber variety and data of fusarium wilt of cucumber was recorded after 7 days intervals after each spray three times. Each treatment was applied in three replications with one control. The spraying of fungicides was done early in the morning with the help of knapsack sprayer.

$\mathrm{T} 1=$ Redomil

$\mathrm{T} 2=$ Score

$\mathrm{T} 3=$ Copper oxychloride

$\mathrm{T} 4=$ Cabriotop

$\mathrm{T} 5=$ Antracol

$\mathrm{T} 6=$ Control

\subsection{Appraisal of Different Chemicals against Fusarium Wilt of Cucumber in Lab}

Table 1. ANOVA for in vitro evaluation of different chemicals against Fusarium oxysporum f.sp. cucumerinum

\begin{tabular}{|c|c|c|c|c|c|}
\hline SOV & DF & SS & MS & F & $\mathrm{P} \geq \mathrm{F}$ \\
\hline Rep (R) & 2 & 1.01 & 0.50 & & \\
\hline $\begin{array}{c}\text { Treatments } \\
(\mathrm{T})\end{array}$ & 5 & 72.03 & 14.40 & 1051.78 & $0.00^{*}$ \\
\hline Conc. (C) & 2 & 0.27 & 0.13 & 9.96 & $0.00^{*}$ \\
\hline Days (D) & 2 & 129.25 & 64.62 & 4718.24 & $0.00^{*}$ \\
\hline $\mathrm{T} \times \mathrm{C}$ & 10 & 0.65 & 0.06 & 4.81 & $0.00^{*}$ \\
\hline $\mathrm{T} \times \mathrm{D}$ & 10 & 7.57 & 0.75 & 55.27 & $0.00^{*}$ \\
\hline $\mathrm{C} \times \mathrm{D}$ & 4 & 0.10 & 0.02 & 1.93 & $0.11^{* *}$ \\
\hline $\mathrm{T} \times \mathrm{C} \times \mathrm{D}$ & 20 & 0.25 & 0.01 & 0.92 & $0.56^{* *}$ \\
\hline Error & 106 & 1.45 & 0.01 & & \\
\hline Total & 161 & 212.61 & & & \\
\hline
\end{tabular}

$$
*=\text { significant }
$$

$* *=$ non-significant
All Treatments (T), Concentrations (C), Days (D), and their interactions $(T \times C)$ and $(T \times D)$ expressed significant results against fusarium wilt of cucumber while interaction between Treatment and Days $(T \times D)$, Concentration and Days $(\mathrm{C} \times \mathrm{D})$ and Treatment, Concentration and Days $(T \times C \times D)$ exhibited non-significant results (Table. 1$)$.

Minimum mycelial growth of fungus was observed by Redomil $(1.53 \mathrm{~cm})$ followed by Score $(1.66 \mathrm{~cm})$, Copper oxychloride $(1.75 \mathrm{c})$, Cabriotop $(1.79 \mathrm{~cm})$, Antracol $(1.90)$ as compared to control $(3.49 \mathrm{~cm})$ (Table 2).

Table 2. Means of mycelial growth of different chemicals against Fusarium oxysporum f.sp. cucumerinum

\begin{tabular}{|c|c|c|}
\hline Sr\# & Treatments & Mycelial growth $(\mathrm{cm})$ \\
\hline $\mathrm{T} 1$ & Redomil & $1.53 \mathrm{e}$ \\
\hline $\mathrm{T} 2$ & Score & $1.66 \mathrm{~d}$ \\
\hline $\mathrm{T} 3$ & Copper oxychloride & $1.75 \mathrm{c}$ \\
\hline $\mathrm{T} 4$ & Cabriotop & $1.79 \mathrm{c}$ \\
\hline $\mathrm{T} 5$ & Antracol & $1.90 \mathrm{~b}$ \\
\hline $\mathrm{T} 6$ & Control & $3.49 \mathrm{a}$ \\
\hline & LSD & 0.06 \\
\hline
\end{tabular}

Mean values in this column having similar letters do not differ significantly as determined by the LSD test $(\mathrm{P} \leq 0.05)$.

Minimum mycelial growth of fungus was observed at concentration one $(1.96 \mathrm{~cm})$ followed by concentration two $(2.06 \mathrm{~cm})$ and concentration three $(2.03 \mathrm{~cm})$ (Table 3).

Table 3. Means of mycelial growth percentage produced by different concentrations of chemicals against Fusarium oxysporum f.sp. cucumerinum

\begin{tabular}{|c|c|c|}
\hline Sr\# & Concentration of treatment & Mycelial growth $(\mathrm{cm})$ \\
\hline 1 & I & $1.96 \mathrm{~b}$ \\
\hline 2 & II & $2.06 \mathrm{a}$ \\
\hline 3 & III & $2.03 \mathrm{a}$ \\
\hline LSD & \multicolumn{2}{|c|}{0.04} \\
\hline
\end{tabular}

Mean values in this column having similar letters do not differ significantly as determined by the LSD test $(\mathrm{P} \leq 0.0$

Minimum mycelial growth was observed after first days interval $(0.97 \mathrm{~cm})$ followed by $2^{\text {nd }}(1.93 \mathrm{~cm})$ and $3^{\text {rd }}(3.15 \mathrm{~cm})$ (Table 4).

Table 4. Comparison of means of mycelial growth produced by different incubation periods of chemicals against Fusarium oxysporum f.sp. cucumerinum

\begin{tabular}{|c|c|c|}
\hline Sr\# & Incubation periods (Days) & Means of mycelial growth (cm) \\
\hline 1 & I & $0.97 \mathrm{c}$ \\
\hline 2 & II & $1.93 \mathrm{~b}$ \\
\hline 3 & III & $3.15 \mathrm{a}$ \\
\hline LSD & \multicolumn{2}{|c|}{0.44} \\
\hline
\end{tabular}

Mean values in this column having similar letters do not differ significantly as determined by the LSD test $(\mathrm{P} \leq 0.05)$. 
Table 5. Comparison of means of mycelial growth produced by different concentrations with treatments of chemicals against Fusarium oxysporum f.sp. cucumerinum

\begin{tabular}{|c|c|c|c|c|c|c|}
\hline \multirow{2}{*}{ Conc. } & \multicolumn{7}{|c|}{ Treatments } \\
\cline { 2 - 7 } & Redomil & Score & $\begin{array}{c}\text { Copper } \\
\text { oxychloride }\end{array}$ & Cabriotop & Antracol & Control \\
\hline I & $1.49 \mathrm{j}$ & $1.62 \mathrm{ghi}$ & $1.71 \mathrm{defg}$ & $1.77 \mathrm{de}$ & $1.78 \mathrm{de}$ & $3.43 \mathrm{~b}$ \\
\hline II & $1.53 \mathrm{ij}$ & $1.66 \mathrm{fgh}$ & $1.75 \mathrm{def}$ & $1.77 \mathrm{de}$ & $1.98 \mathrm{c}$ & $3.70 \mathrm{a}$ \\
\hline III & $1.58 \mathrm{hij}$ & $1.58 \mathrm{hij}$ & $1.79 \mathrm{de}$ & $1.82 \mathrm{~d}$ & $1.94 \mathrm{c}$ & $3.34 \mathrm{~b}$ \\
\hline LSD & \multicolumn{7}{|c|}{0.10} \\
\hline
\end{tabular}

Mean values in this column having similar letters do not differ significantly as determined by the LSD test $(\mathrm{P} \leq 0.05)$.

Table 6. Interaction of means of mycelial growth produced by different treatments and incubation periods (T×D) against Fusarium oxysporum f.sp. cucumerinum

\begin{tabular}{|c|c|c|c|c|}
\hline \multirow{2}{*}{ Sr\# } & \multirow{2}{*}{ Treatments } & \multicolumn{3}{|c|}{ Incubation periods (Days) } \\
\cline { 3 - 5 } & & After 3 days & After 6 days & $\begin{array}{c}\text { After } 9 \\
\text { Days }\end{array}$ \\
\hline T1 & Redomil & $0.55 \mathrm{n}$ & $1.49 \mathrm{j}$ & $2.56 \mathrm{e}$ \\
\hline $\mathrm{T} 2$ & Score & $0.68 \mathrm{~m}$ & $1.60 \mathrm{ij}$ & $2.70 \mathrm{~d}$ \\
\hline $\mathrm{T} 3$ & Copperoxychloride & $0.76 \mathrm{~lm}$ & $1.67 \mathrm{hi}$ & $2.82 \mathrm{c}$ \\
\hline $\mathrm{T} 4$ & Cabriotop & 0.861 & $1.75 \mathrm{gh}$ & $2.76 \mathrm{~cd}$ \\
\hline $\mathrm{T} 5$ & Antracol & $1.04 \mathrm{k}$ & $1.85 \mathrm{fg}$ & $2.82 \mathrm{c}$ \\
\hline $\mathrm{T} 6$ & Control & $1.94 \mathrm{f}$ & $3.26 \mathrm{~b}$ & $5.26 \mathrm{a}$ \\
\hline & LSD & \multicolumn{3}{|c}{} \\
\hline
\end{tabular}

Mean values in this column having similar letters do not differ significantly as determined by the LSD test $(\mathrm{P} \leq 0.05)$.

At $1 \%$ concentration the minimum mycelial growth was observed by Redomil $(1.49 \mathrm{~cm})$ followed by Score $(1.62 \mathrm{~cm})$, Copper oxychloride $(1.71 \mathrm{~cm})$, Cabriotop $(1.77 \mathrm{~cm})$, Antracol $(1.78 \mathrm{~cm})$ as compared to control $(3.43 \mathrm{~cm})$. At $0.5 \%$ concentration the minimum mycelial growth was observed by Redomil $(1.53 \mathrm{~cm})$ followed by Score $(1.66 \mathrm{~cm})$, Copper oxychloride $(1.75 \mathrm{~cm})$, Cabriotop $(1.77 \mathrm{~cm})$, Antracol $(1.98 \mathrm{~cm})$ as compared to control $(3.70 \mathrm{~cm})$. At $0.25 \%$ concentration the minimum mycelial growth was observed by Redomil $(1.58 \mathrm{~cm})$ followed by Score $(1.58 \mathrm{~cm})$, Copper oxychloride $(1.79 \mathrm{~cm})$, Cabriotop $(1.82 \mathrm{~cm})$, Antracol $(1.94 \mathrm{~cm})$ as compared to control $(3.34 \mathrm{~cm})$ (Table 5).

After 3 days the minimum mycelial growth was observed by Redomil $(0.55 \mathrm{~cm})$ followed by Score $(0.68 \mathrm{~cm})$, Copper oxychloride $(0.76 \mathrm{~cm})$, Cabriotop $(0.86 \mathrm{~cm})$, Antracol $(1.04$ $\mathrm{cm})$ as compared to control $(1.94 \mathrm{~cm})$. After 6 days the minimum mycelial growth was observed by Redomil (1.49 $\mathrm{cm})$ followed by Score $(1.60 \mathrm{~cm})$, Copper oxychloride $(1.67$ $\mathrm{cm})$, Cabriotop $(1.75 \mathrm{~cm})$, Antracol $(1.85 \mathrm{~cm})$ as compared to control $(3.26 \mathrm{~cm})$. After 9 days the minimum mycelial growth was observed by Redomil $(2.56 \mathrm{~cm})$ followed by Score $(2.70 \mathrm{~cm})$, Copper oxychloride $(2.82 \mathrm{~cm})$, Cabriotop $(2.76 \mathrm{~cm})$, Antracol $(2.82 \mathrm{~cm})$ as compared to control $(5.26$ cm) (Table 6).

\section{Results}

\subsection{Appraisal of Different Chemicals against Fusarium Wilt of Cucumber in Field}

All Treatments (T), Concentrations (C), Days (D), and their interactions $(\mathrm{T} \times \mathrm{C})$ and $(\mathrm{T} \times \mathrm{D})$ Treatment and Days
$(\mathrm{T} \times \mathrm{D})$, Concentration and Days $(\mathrm{C} \times \mathrm{D})$ and Treatment, Concentration and Days $(\mathrm{T} \times \mathrm{C} \times \mathrm{D})$ expressed significant results against fusarium wilt of cucumber (Table 7).

Maximum reduction in disease was expressed by Redomil $(47.50 \%)$ followed by Score $(49.72 \%)$ as compared to control (55\%) (Table 8).

Minimum disease incidence was observed at $1 \%$ concentration $(49.72 \%)$ followed by $0.5 \%$ concentration (51\%) and $0.25 \%$ concentration $(51.50 \%)$ (Table 9$)$.

The disease incidence after one week interval of spray was $(52.37 \%)$ and after two weeks it was (49.11\%) (Table 10).

At $1 \%$ concentration the maximum disease reduction has been expresses by Redomil (46\%) followed by Score $(48.16 \%)$ as compared to control (55\%). At $0.5 \%$ concentration the maximum disease reduction has been expresses by Redomil (47.50\%) followed by Score (50.50\%) as compared to control (55\%). At $0.25 \%$ concentration the maximum disease reduction has been expresses by Redomil (49\%) followed by Score $(50.50 \%)$ as compared to control $(55 \%)$ (Table 11).

After 7 days of data recording the minimum disease incidence was expressed by Redomil (50\%) followed by score $(52.11 \%)$ as compared to control (55\%). After 14 days of data recording the minimum disease incidence was expressed by Redomil (45\%) followed by score $(47.33 \%)$ as compared to control (55\%) (Table 12).

At $1 \%$ concentration the disease incidence was $(51.11 \%)$ after 7 days and after 14 days it was (48.33\%). At $0.5 \%$ concentration the disease incidence was $(52.66 \%)$ after 7 days and after 14 days it was (49.33\%). At $0.25 \%$ concentration the disease incidence was $(53.33 \%)$ after 7 days and after 14 days it was (49.66\%) (Table 13$)$. 
At $1 \%$ concentration of first spray the minimum disease incidence was observed by Redomil (48\%) followed by Score $(50.33 \%)$ as compared to control (55\%). At $0.5 \%$ concentration of first spray the minimum disease incidence was observed by Redomil (50\%) followed by Score (53\%) as compared to control (55\%). At $0.25 \%$ concentration of first spray the minimum disease incidence was observed by Redomil (52\%) followed by Score (53\%) as compared to control $(55 \%)$ ).At $1 \%$ concentration of second spray the minimum disease incidence was observed by Redomil (44\%) followed by Score (46\%) as compared to control (55\%). At $0.5 \%$ concentration of first spray the minimum disease incidence was observed by Redomil (45\%) followed by Score $(48 \%)$ as compared to control $(55 \%)$. At $0.25 \%$ concentration of first spray the minimum disease incidence was observed by Redomil (46\%) followed by Score (48\%) as compared to control (55\%) (Table 14).

Table 7. ANOVA for in vitro evaluation of different chemicals against Fusarium wilt of cucumber

\begin{tabular}{|c|c|c|c|c|c|}
\hline SOV & DF & SS & MS & F & $\mathrm{P} \geq \mathrm{F}$ \\
\hline $\begin{array}{c}\text { Treatments } \\
(\mathrm{T})\end{array}$ & 2 & 534.25 & 267.13 & 7839.67 & $0.00^{*}$ \\
\hline Conc. $(\mathrm{C})$ & 2 & 30.25 & 15.13 & 444.02 & $0.00^{*}$ \\
\hline Days (D) & 1 & 143.40 & 143.40 & 4208.70 & $0.00^{*}$ \\
\hline $\mathrm{T} \times \mathrm{C}$ & 4 & 18.51 & 4.63 & 135.87 & $0.00^{*}$ \\
\hline $\mathrm{T} \times \mathrm{D}$ & 2 & 71.81 & 35.90 & 1053.80 & $0.00^{*}$ \\
\hline $\mathrm{C} \times \mathrm{D}$ & 2 & 1.81 & 0.90 & 26.63 & $0.00^{*}$ \\
\cline { 1 - 4 } $\mathrm{T} \times \mathrm{C} \times \mathrm{D}$ & 4 & 1.63 & 0.04 & 11.96 & $0.00^{*}$ \\
\cline { 1 - 4 } Error & 36 & 1.22 & 0.03 & & \\
\cline { 1 - 4 } Total & 53 & 0.124 & & & \\
\cline { 1 - 4 }
\end{tabular}

*= significant, All the results were significant.

Table 8. Means of disease incidence of different chemicals against Fusarium oxysporum f.sp. cucumerinum

\begin{tabular}{|c|c|c|}
\hline Sr\# & Treatments & Disease incidence (\%) \\
\hline $\mathrm{T} 1$ & Redomil & $47.50 \mathrm{c}$ \\
\hline $\mathrm{T} 2$ & Score & $49.72 \mathrm{~b}$ \\
\hline $\mathrm{T} 3$ & Control & $55.00 \mathrm{a}$ \\
\hline \multicolumn{2}{|c|}{ LSD } & 0.124 \\
\hline
\end{tabular}

Mean values in this column having similar letters do not differ significantly as determined by the LSD test $(\mathrm{P} \leq 0.05)$.

Table 9. Means of disease incidence percentage produced by different concentrations of chemicals against Fusarium oxysporum f.sp. cucumerinum

\begin{tabular}{|c|c|c|}
\hline Sr\# & Concentration of treatment & Disease incidence (\%) \\
\hline 1 & I & $49.72 \mathrm{c}$ \\
\hline 2 & II & $51.00 \mathrm{~b}$ \\
\hline 3 & III & $51.50 \mathrm{a}$ \\
\hline LSD & \multicolumn{2}{|c|}{0.124} \\
\hline
\end{tabular}

Mean values in this column having similar letters do not differ significantly as determined by the LSD test $(\mathrm{P} \leq 0.05)$.
Table 10. Comparison of means of disease incidence percentage produced by different concentrations of chemicals against Fusarium oxysporum f.sp. cucumerinum

\begin{tabular}{|c|c|c|}
\hline Sr\# & Incubation periods (Days) & Disease incidence (\%) \\
\hline 1 & I & $52.37 \mathrm{a}$ \\
\hline 2 & II & $49.11 \mathrm{~b}$ \\
\hline LSD & \multicolumn{2}{|c|}{0.101} \\
\hline
\end{tabular}

Mean values in this column having similar letters do not differ significantly as determined by the LSD test $(\mathrm{P} \leq 0.05)$.

Table 11. Comparison of means of disease incidence percentage by different concentrations of treatments against Fusarium wilt of cucumber

\begin{tabular}{|c|c|c|c|}
\hline \multirow{2}{*}{ Conc. } & \multicolumn{3}{|c|}{ Treatments } \\
\cline { 2 - 4 } & Redomil & Score & Control \\
\hline $1 \%$ & $46 \mathrm{f}$ & $48.16 \mathrm{~d}$ & $55 \mathrm{a}$ \\
\hline $0.5 \%$ & $47.50 \mathrm{e}$ & $50.50 \mathrm{~b}$ & $55 \mathrm{a}$ \\
\hline $0.25 \%$ & $49 \mathrm{c}$ & $50.50 \mathrm{~b}$ & $55 \mathrm{a}$ \\
\hline LSD & \multicolumn{3}{|c}{0.216} \\
\hline
\end{tabular}

Mean values in this column having similar letters do not differ significantly as determined by the LSD test $(\mathrm{P} \leq 0.05)$.

Table 12. Interaction of means of disease incidence produced by different treatments and incubation periods $(T \times D)$ against fusarium wilt of cucumber

\begin{tabular}{|c|c|c|c|}
\hline \multirow{2}{*}{ Sr\# } & \multirow{2}{*}{ Treatments } & \multicolumn{2}{|c|}{ Incubation periods (Days) } \\
\cline { 3 - 4 } & & After 7 days & After 14 days \\
\hline T1 & Redomil & $50 \mathrm{c}$ & $45 \mathrm{e}$ \\
\hline T2 & Score & $52.11 \mathrm{~b}$ & $47.33 \mathrm{~d}$ \\
\hline T3 & Control & $55 \mathrm{a}$ & $55 \mathrm{a}$ \\
\hline \multicolumn{3}{|c}{0.176} \\
\hline
\end{tabular}

Mean values in this column having similar letters do not differ significantly as determined by the LSD test $(\mathrm{P} \leq 0.05)$.

Table 13. Comparison of means of disease incidence percentage produced by different concentrations of chemicals against fusarium wilt of cucumber

\begin{tabular}{|c|c|c|}
\hline \multirow{2}{*}{ Conc. } & \multicolumn{2}{|c|}{ Days } \\
\cline { 2 - 3 } & After 7 days & After 14 days \\
\hline I & $51.11 \mathrm{c}$ & $48.33 \mathrm{f}$ \\
\hline II & $52.66 \mathrm{~b}$ & $49.33 \mathrm{e}$ \\
\hline III & $53.33 \mathrm{a}$ & $49.66 \mathrm{~d}$ \\
\hline LSD & \multicolumn{2}{|c}{0.176} \\
\hline
\end{tabular}

Mean values in this column having similar letters do not differ significantly as determined by the LSD test $(\mathrm{P} \leq 0.05)$.

Table 14. Comparison of means of disease incidence by chemicals to sprays and their concentration against Fusarium wilt of cucumber

\begin{tabular}{|c|c|c|c|c|c|c|}
\hline \multirow{3}{*}{ Treatments } & \multicolumn{5}{|c|}{ First spray } & \multicolumn{3}{c|}{ Second spray } \\
\cline { 2 - 7 } & \multicolumn{7}{|c|}{ Concentrations } \\
\cline { 2 - 7 } & I & II & III & I & II & III \\
\hline Redomil & $48 \mathrm{f}$ & $50 \mathrm{e}$ & $52 \mathrm{c}$ & $44 \mathrm{i}$ & $45 \mathrm{~h}$ & $46 \mathrm{~g}$ \\
\hline Score & $50.33 \mathrm{~d}$ & $53 \mathrm{~b}$ & $53 \mathrm{~b}$ & $46 \mathrm{~g}$ & $48 \mathrm{f}$ & $48 \mathrm{f}$ \\
\hline Control & $55 \mathrm{a}$ & $55 \mathrm{a}$ & $55 \mathrm{a}$ & $55 \mathrm{a}$ & $55 \mathrm{a}$ & $55 \mathrm{a}$ \\
\hline LSD & \multicolumn{7}{|c|}{0.305} \\
\hline
\end{tabular}

Mean values in this column having similar letters do not differ significantly as determined by the LSD test $(\mathrm{P} \leq 0.05)$. 


\section{Discussion}

This work is an active implement to manage fusarium wilt disease caused by pathogen (Fusarium oxysporum f.sp. cucumerinum) of cucumber crop. For this purpose the research trial of the most susceptible variety Local was conducted and this was sprayed three times and with three concentrations. Redomil expressed the maximum fungal growth inhibition $(1.53 \mathrm{~cm})$ followed by Score $(1.66 \mathrm{~cm})$, Copper oxychloride $(1.75 \mathrm{~cm})$, Cabriotop $(1.79 \mathrm{~cm})$, and Antracol $(1.90 \mathrm{~cm})$ as compared to control $(3.49 \mathrm{~cm})$. Their best results were applied to field. Maximum inhibition of disease incidence was expressed by Redomil (50\%) followed by Score $(52.22 \%)$ as compared to control $(55 \%)$.These results are in agreement with those of (Nisa et al., 2011) in this seven fungicides (myclobutanil, hexaconzol, captan, carbendazim, mencozeb, zineb and bitertanol) were tested against spore growth and mycelia development of Fusarium oxysporum. Hexaconozole @ 1000 ppm abridged the mycelia growth development fully as compared to rest of all fungicidal chemicals at same rate.

Comparing effectiveness of systemic, non-systemic and various fungicides was assessed in vitro and in vivo to control Fusarium oxysporum causing wilt diseases. Carbendazim and benomyl totally blocked the growing of the check fungus monitored by thiophanate methyl, aureofungin, bitertinol. In field situations carbendazim and benomyl abridged the wilt frequency winning to 80 to $73 \%$ respectively [19].

Seven fungicides (myclobutanil, hexaconzol, captan, carbendazim, mencozeb, zineb and bitertanol) were applied to judge the result on spore growth and mycelia development of Fusarium oxysporum. Hexaconozole on application 1000 ppm reduced the mycelia growth development fully subsequent by rest of all fungicidal chemicals at same rate [18].

\section{Conclusions}

Fusarium wilt of cucumber of $1.53 \mathrm{~cm}$ and $50 \%$ was recorded by Redomil. It was the best applied fungicide against Fusarium wilt attack. This fungicide, because of its good performance of minimizing disease of fusarium wilt is better against fusarium wilt incidence. Among other fungicides Score $1.66 \mathrm{~cm}$ and $52.22 \%$ was recorded. As other fungicides gave less efficiency in labortatory condition Copper oxychloride $(1.75 \mathrm{~cm})$, Cabriotop $(1.79 \mathrm{~cm})$, and Antracol $(1.90 \mathrm{~cm})$ as compared to control $(3.49 \mathrm{~cm})$ so they were not applied in field.

\section{REFERENCES}

[1] R. A. T. George. Vegetable Seed Production. Pitman Press, Bath, U.K. , 1985.
[2] N. Shetty, T. C. Wehner. Screening the Cucumber germplasm Collection for Fruit Yield and Quality. Crop Science. 42: 2174-2183, 2002.

[3] T. W. Whitaker, G. N. Davis. Cucurbits: Botany, Cultivation and utilization. Interscience, New York, 1962.

[4] O. Adetula, L. Denton. Performance of vegetative and yield accessions of cucumber (Cucumis sativa L.) Horticultural Society of Nigeria (HORTSON) Proceedings of 21st annual conference 10-13, 2003.

[5] P. Vimala, C. C. Ting, H. Salbiah, B. Ibrahim, L. Ismail. Biomass production and nutrient yields of four green manures and their effects on the yield of cucumber. Journal of Tropical Agric and Food Science 27:47-55, 1999.

[6] A. Zakeria, P. Viamala. Research and development of organic crop production in Malaysian. Paper presented at the "Export group workshop on preparation of technical guidelines or organic cultivation of tropical and sub-tropical fruits 22-26, 2002 .

[7] J. Duke. The green pharmacy. St Martins Press, New York, 1997.

[8] Y. H. Wang, T. Joobeur, R. A. Dean, J. E. Staub. Cucurbits. Genome Mapping and Molecular Breeding in Plants 5: Vegetables. 2007.

[9] Anonymous. Statistics of Pakistan 2010-11. Government of Pakistan, Ministry of Food, Agriculture and Livestock division. Economic Wing, Islamabad, 2010.

[10] GOP. Statistics of Pakistan 2010-11. Government of Pakistan, Ministry of Food, Agriculture and Livestock division. Economic Wing, Islamabad, 2010.

[11] H. Ikramul, F. J. Farhat. Screening of chickpea lines in the wilt sick plot and effect of environmental temperature on wilt incidence. Proceedings of COMSTECH-NIAB International Workshop on Agroclimatology, pests and diseases and their control. November 21-26, 1992. Faisalabad, Pakistan.

[12] X. G. Zhou, F. Z. Wu, X. Z. Wang, Y. Yuan. Progresses in the mechanism of resistance to Fusarium wilt in cucumber (Cucumis sativus L.) Journal of Northeast Agricultural University (English Edition). 15: 1-6, 2008.

[13] A. K. Mishra, C. H. Liu, B. He, R. X. Tan. Efficacy of isolantolactone, a sesquiterpenes lactonefrom Inula racemosa, as herbal fungi toxicant to control 'take-all' disease of wheat. Int. Pest Control 42: 131-137, 2000.

[14] U. Roth, A. Friebe, H. Schnabl. Resistance induction in plants by a brassinosteroid- containing extract of Lychnis viscaria $L$. Zeitschrift fur Naturfor schung section. C. Biosciences. 55: 552-559, 2000.

[15] R. K. Mujeebur, M. K. Shahana. Effect of root-dip treatment with certain phosphate solubilizing microorganism on Fusarium wilt of tomato. Bio Resources Technology. 85: 213-215, 2002

[16] S. Chung, H. Kong, J. S. Buyer, D. K. Lak shman, J. Lydon, S. D. Kim, D. P. Roberts. Isolation and partial characterization of Bacillus subtilis ME4 88 for suppression of soil borne pathogens of cucumber and pepper. Appl. Microbiol. and Biotechnol. 80: 115 -123, 2008.

[17] P. Sharma. Evaluation of disease control and plant growth promotion potential of biocontrol agents on Pisum sativum 
and comparison of their activity with popular chemical control agent-carbendazim. Journal of Toxicology and Environmental Health Science. 3: 127-138, 2011.

[18] T. Nisa, A. H. Wani, M. Y. Bhat, S. A. Pala, R. A. Mir. In vitro inhibitory effect fungicides and botanicals on mycelia growth and spore germination of Fusarium oxysporum. Journal of Biopesticides. 4: 53-56, 2011.

[19] S. Sunita, R. Katoch. Chemical control of Fusarium oxysporum f.sp. dianthi, an incitant of carnation wilt. Indian J. Microbiol. 41: 135-137, 2001. 